\title{
Unequal status of equal peoples: Causes and ways to address the problem
}

\author{
Dzhamal Z. Mutagirov \\ Department of Political Sciences, \\ St. Petersburg State University, Russia
}

\begin{abstract}
Pondering over the situation in the world, and over the nature of the relations between peoples and causes of the conflicts, it is impossible not to see that the States and ruling in them circles are the source of many of them, as a rule the most negative and destructive. An impression forms here that the real politics of these 'institutions for the protection of human and peoples ' rights, as well as their security' (Jefferson), aims to erect on the smooth way to the humankind's and people's free development all sorts of bumps and obstacles, which they then 'heroically overcome', calling it a 'global politics'. The main reasons for disharmony in international life and conflicts in the world so far remain inequality of individuals and peoples, and attempts of some States to perpetuate this status, on the one hand, and a natural aspiration of peoples to equality, autonomy and progress, on the other. In the article, whose author is the philosopher of history, politics and law, is shown the causes for multi-directional activities of the peoples and their States, civil and political societies, as well as possible ways to solve them. Management of global processes in accordance with the will of the peace-loving and creative labor peoples and humanity as a whole, rather than of narrow groups of politicians, traditionally guiding by the principle 'divide and rule', is considered as the best way to.
\end{abstract}

Keywords: people, society, civil society, the state, autonomy, self-determination, the will of the people, international law, legitimacy.

\section{INTRODUCTION}

Man forms all communities - families, peoples, societies, States and humankind as a whole, each of which gives him some status - of a member of a family and society, country's resident, citizen of the state, representative of a particular nation and entire humankind. Some of these communities are folded in a natural way, are objective realities for people, the others are formed by people for optimization of their living standards.

Family and society are voluntary associations of people to solve together life's problems, which are impossible or difficult to do alone. To solve them, societies shape many institutions, one of which is the state. Each of these institutions is called to solve some specific problems of public life.

Since ancient times people have been thinking of the ratio, as well as of the relationship of human institutions, first and foremost, of the society and the State and over the ways to their optimization. One of the first responses to this question was contained in the Indian treatise 'Arthashastra': Happiness of his subjects is the happiness of the Ruler, in the use of the subjects - his usefulness.

It was said that the 19th century's French scientist and politician F. Bastiat established a prize in one million Louis to whoever will formulate a clear definition of the State, and that no one 
received it [2, p. 1]. It was not so much about identifying forms and types of the States, but of the purpose, nature, vocation and functions of the political power.

The current definitions of the State are extremely varied and differ from each other, depending on who articulates them: Lawyers, political scientists, or philosophers. Most of them understand the State as a having supreme authority community of people living in a certain territory [2, p. 123 - 124]. But, if we keep in mind that the supreme authority belongs to civil society and only political power is delegated to the State, the focus becomes not quite correct. As we see it, the best and more convincing definition of the State in terms of its place in a structure of the society and its vocation was given in the Declaration of independence of the United States: "We hold these truths to be self-evident, that all men are created equal, that they are endowed by their Creator with certain unalienable Rights, that among these are Life, Liberty and the pursuit of Happiness. - That to secure these rights, Governments are instituted among Men, deriving their just powers from the consent of the governed, - That whenever any Form of Government becomes destructive of these ends, it is the Right of the People to alter or to abolish it, and to institute new Government, laying its foundation on such principles and organizing its powers in such form, as to them shall seem most likely to affect their Safety and Happiness" [3 ].

That is, the State is a serviceable political institution of a society, entirely dependent on created it people and called to serve him, playing the role of his security service: protect the lives and freedoms of the members of society, to ensure their safety, protect their habitat from applicants from the outside, regulate relations with other countries and peoples.

Unfortunately, so far this more than clear and convincing explanation of the vocation of the State did not become an axiom for political scientists, apparently because not all States in the world function as the truly nation's institutions. We will try referring to the experience of history and using logical, comparative, systemic and other methods of research, identify the causes of the remaining inequality of peoples and the ways to remedy it.

\section{THE ACTUAL STATUS THE PEOPLES' RIGHTS}

Do all peoples use their natural and innate rights and, accordingly, the right to form their own governments or only some of them do that? The answer to this legitimate question also contains in the above mentioned Declaration of Independence: all peoples are endowed with such rights.

A society originally forms as a family, kin and tribal, i.e. as an ethnic, based on shared fundamental characteristics. It has been extended by as a voluntary association of ethnic groups with identic value systems so forced annexation of the neighboring peoples with different value systems. In the second case, it is not a real community of the peoples (commonwealth), but an artificial accumulation of unequal and not trusting to each other peoples. So, are there many similarities between Kurds, Tamils, Basques, Irish, Rohindzha, on the one hand, and the dominated (title) peoples in Turkey, Sri Lanka, Spain, Great Britain, Myanmar, etc., on the other? Whose interests and rights objectively would defend the states in those countries? Usually the answer to the question is: They play the role of a designer of law sphere of a society and of the guardian of the legality in it. All is true, but what is the law in such societies, not as an expression of the will citizens' relative majority belonging to the title peoples? [4]. And what to do with the will of unequal ethnic minorities and with their rights to autonomy and self-determination? 
The international covenants on human rights ratified by an absolute majority of the states members of the United Nations recognize that:

1. All peoples have the right of self-determination. By virtue of that right they freely determine their political status and freely pursue their economic, social and cultural development.

2. All peoples may, for their own ends, freely dispose of their natural wealth and resources without prejudice to any obligations arising out of international economic co-operation, based upon the principle of mutual benefit, and international law. In no case may a people be deprived of its own means of subsistence.

3. The States Parties to the present Covenant, including those having responsibility for the administration of Non-Self-Governing and Trust Territories, shall promote the realization of the right of self-determination, and shall respect that right, in conformity with the provisions of the Charter of the United Nations" $[5,6]$.

\section{What is the real situation with implementation of these rights by the peoples of the world?}

According to calculations of the researchers, there were about 600 thousand societies in the known in antiquity world [1, p. 733]. As a result of rivalry and wars between the societies for millennia, some of them disappeared entirely, the others integrated (voluntarily or forcibly) with the stronger, resulting transformation originally mono-ethnic societies and states into multiethnic ones. Many previously independent peoples with different cultures, customs and traditions, often contrary to their will, were annexed by the empires.

Today there are more than nine thousands of different sized language groups [7], about 250 states and self-governing territories in the world, 193 of which are members of the United Nations. It follows from the ciphers that thousands of the peoples do not have their institution for the protection of their rights and freedoms, or have it in a community with other peoples, and about fifty political societies have the status partially recognized or unrecognized states with corresponding to the status limitation of the rights and opportunities as actors of the world politics and international relations.

\section{What is the reason for such inequality of the peoples and is it rightful?}

Socio-political processes in the world, due to the nature and aspirations of their members, always occur inconsistently. Peoples engaged in creative work, first of all civil societies, their socio-economic and spiritual institutions are objectively interested in peaceful relations with each other. They are inherently focused on the relationship of good-neighborliness, equality, mutually beneficial cooperation and common good. The prudent part of humankind has always maintained inequality and dependence of one people from the other, rivalry and enmity between them unnatural phenomena and promoted the idea of self-determination and independence of all peoples without exception.

The states, repeating the words of the English philosopher T. Hobbes, are "in continual jealousies, and in the state and posture of gladiators; having their weapons pointing, and their eyes fixed on one another; that is, their forts, garrisons, and guns upon the frontiers of their kingdoms; and continual spies upon their neighbours; which is a posture of war" [8Hobbes, $p$. 73]. The philosopher identified the State with the biblical Monster Leviathan. Based on this assessment of Hobbes, the German political scientist K. Schmidt believed that the modern State is a civil war, constantly unbridled by strong power, the most important pillars of which are the praetorian guards (army and police) [9, p. 132, 147]. The most powerful of them disregard the human values and natural norms of relations between peoples. Morality as general criterion for defining the conduct of states and, above all, as a yardstick to measure and compare the 
behavior of various states is not valid here. More sad, more limited and more practical criteria prevail here [10Kennan, 1952, p. 49]. There are even politics who try to justify such behavior, believing that "the state in the face of anarchy could not afford to be moral" [11Spykman, 1951, p. 9] and "power is not searched for the sake of moral values; on the contrary, moral values are used to achieve power "[12Ibid., p. 18].

Different orientations of the peoples and their political institutions, as well as dissimilarities of their understanding of the international relations' norms logically engendered contradictory rules and principles of international law [13, p. 14-16]. They are the principles of territorial integrity and inviolability of the frontiers, on the one hand, and the right of the peoples to determine their own destiny, on other. It is clear that perpetuation of territorial integrity and inviolability of the state borders formed in the feudal and imperial times, excludes any possibility of the peoples, forcibly included into these empires, to implement their right to selfdetermination and to create their own states. Similarly, the implementation of the right to selfdetermination leads to automatic shrinking the multi-ethnic states' territory with changing of their borders - to crushing of the empires, federations and unions into many separate states. This had taken place on the territories of the former Austro-Hungarian, British, Ottoman, Russian Empires, Soviet Union, Czechoslovakia, Yugoslavia and inevitably will continue in now multinational states until there remains any inequality of the ethnic groups.

Seemingly, these are natural processes. Families of both individuals and peoples arise and some of them crash for one reason or another. When people try to realize their legitimate right to live on their own, the multinational states, considering that this may weak their influence in the world, have a 'legitimate' opportunity, referring to the fixed in the UN Charter principles of territorial integrity and inviolability of the State borders, not let them to implement their will and to persuade 'fellow leviathans' not recognize the newly formed institutions. So there are categories of the 'recognized', 'partially recognized' and 'unrecognized' states in the world.

When before transparent administrative borders between former republics of the socialist federations suddenly turned in the 1980-1990 's into external ones with customs, some peoples refused to accept the new order of things, set against their will, and proclaimed their independence. These were Nagorno-Karabakh with the predominantly Armenian population, which was previously part of Azerbaijan with a status of autonomy, and revolted against Baku after deprivation of its autonomy; Abkhazia, voluntarily entered into Russia and the South Ossetia united with Georgia with the purpose to facilitate an administrative management; Pridnestrovian Moldavian Republic; Kosovo, which had repeated the fate of Nagorno-Karabakh (former autonomy within Serbia, denied of that status because of the exacerbation of interethnic relations in the Yugoslavian Federation); Donetsk and Luhansk people's Republics, which refused accept the ant constitutional coup d'état in Kiev 2014. Some of them (Kosovo, Timor-Este, Darfur) have been immediately recognized by many states, refusing the same to the others on the basis of their likes and dislikes, as well as on certain geopolitical considerations.

The persuasion for greater autonomy is common for many peoples of the multinational states. It occurs in the Canadian province of Quebec with the predominantly French-speaking population, in Belgium, Scotland, Catalonia and the Basque country in Spain, and so on. There is a reason to suppose that all peoples of now multinational states will sooner or later strive to a greater degree of autonomy, if these states will not transform into a truly democratic federations of nations, in which each of them would feel as an equal member living comfortably, in accordance with their ethnic systems of values. 
That is the best way to avoid any contradictions between the principles of territorial integrity and inviolability of the frontiers of the states, on the one hand, and the peoples' right to selfdetermination, on the other hand, may become affording an opportunity to all the peoples of the multinational societies to use their natural rights within these societies, transforming them into democratic federations with wide autonomy of all their nationalities. But the authorities, traditionally considering the multi-ethnic country and its resources as their own property, are striving to avoid any weakening of their power and try to negate the rights of ethnic minorities, resorting even to repressions. It is sufficing to recall the events foregoing to the movements for self-determination in Nagorno-Karabakh, Abkhazia, East Timor, Kosovo, southern Sudan (Darfur), Eastern Ukraine, Iraqi Kurdistan, Catalonia and other regions of the world. The unwillingness of the authorities of the states to respect the ethnic minorities' legitimate aspirations to live autonomously and reprisals are forcing the last to fight for complete independence from such authorities and to take their destiny into their own hands.

How ewer, it is impossible to force the person and peoples to live by stranger, and sometimes alien to them laws. Only coincidence of the fundamental interests of all members of multiethnic societies and full accounting them by public institutions are able to maintain their unity and integrity. If there is no such coincidence, the nations, conceiving their legitimate rights, will try to form their own states. Fragmentation of multinational societies to many new and autonomous entities, as happened as a result of the collapse of the Empires after the First World War, and disintegration of the unions and federations in 1980-1990-ies would be a result. Sooner or later the current multinational societies and states will repeat the same fate if they will not undergo transformation toward equality of all constituent peoples.

Any acts against territorial integrity and of any society and state borders violation from the outside through aggression and intervention really should be unacceptable. But disintegration of some societies and states, as well as families, occurs for reasons of incompatibility of the interests, aspirations and legal statuses of their members. Legal norms and law procedures in cases of spouses' divorce had been in detail defined by national law in the twentieth century. It is necessary to elaborate such norms and procedures for regulating the disintegration of the 'families of peoples'.

Society is one of the first institutions of man and an objective reality, the existence of which reasonable people cannot deny. Its economic, social and spiritual institutions, without which human life is impossible, also are objective realities. The society establishes the State as its security service, as an institution for the protection of the rights and security of its members. Therefore, the true criteria of the democratic and law abiding national State are: It is established by the will the of the constitutional majority of the society, consisting of a specific ethnicity or group of the ethnicities with similar systems of national values, and having their historical habitat as well as their traditional institutions.

The law of nation is a legitimized will not its first persons or a small group of politicians as this, mistakenly, understand in many countries, but the legitimately expressed will of the constitutional majority the society's members, determined by the natural conditions of their habitat. If the State does not fulfil its obligations to society and acts unlawfully and willfully, the above-mentioned United States Declaration of independence rightly proclaimed, "it is the Right of the People to alter or to abolish it, and to institute new Government, laying its Foundation on such Principles, and organizing its Powers in such Form, as to them shall seem most likely to effect their Safety and Happiness" [ЗДжефферсон, 1990]. As far as we know, no one, except for authoritarian rulers and their adepts, do not put under a question the reasonableness of the 
ideas of the Declaration. It was and remains one of the outstanding democracy's charters, though some descendants of its authors themselves are not always adhered to its ideas.

The main legitimate basis of statehood is, once again repeating this maxim, the people themselves are its founder and the only judge. In the modern world it is determined by elections and referenda held, in order to avoid any possibility of fraud and forgeries, under broad national and international control. They are held in the constituent entities or areas of the ethnic groups, who want to exercise their right to self-determination, but in no case in entire multi-ethnic state as central authorities of these states wont. If the states are formed in strict compliance with these conditions, they become de facto and de jure realities, regardless of attitude of anyone from the outside. Their stability is determined primarily by the degree of unity of the members of the ethnic group and its creativity.

It is necessary to be realistic and recognize inconsistency even of some proponents of the right to self-determination and their contradictory approaches to the historical practice of peoples. So, recognizing with willingness the right to self-determination for peoples in deemed unfriendly states, they deny it for their own peoples, leaving this issue to the discretion of the multinational community where the proponents of the right to self-determination, as a rule, tend to be in the minority.

Only original ethnicities, living in their historic homeland from generation to generation, have the right to self-determination up to creation of their own states. The peoples' diasporas, whose historical homeland are outside the country of their residence, cannot pretend to the right to self-determination in such a large scale. Attempts of various opposition and hostile to the constitutional socio-political systems groups, gangs or random persons to declare certain areas temporarily trapped under their control 'independent states' could not be considered legitimate at all. At the beginning of the XXI century there were several dozens of such ephemeral or virtual 'states' (so-called 'Sea land', 'Amirat of the Caucasus', 'Islamic State', etc.). This is roughly the same as the grievous practice in some countries, when mafias declare certain areas of settlements 'spheres of their influence' and collect tribute from all persons having a business here.

The State as an actor of international law should possess the following qualifications: a) a permanent population; b) a defined territory; c) government; and d) capacity to enter into relations with the other states [14Конвенция, 1933, Article 1]. In accordance with the third article of the 'Convention on Rights and Duties of States' (signed at Montevideo, December 26, 1933), "the political existence of the State is independent of recognition by the other states. Even before recognition the state has the right to defend its integrity and independence, to provide for its conservation and prosperity, and consequently to organize itself as it sees fit, to legislate upon its interests, administer its services, and to define the jurisdiction and competence of its courts". The exercise of these rights has no other limitation than respect the rights of the other states according to international law. It is considered that the population of the state as a society's political institution must be indigenous, but the size of the territory and population, which are very important to the state, are not recognized as determinants. Hence, there are the mini states like the Vatican (or Holy See) with territory in 40 hectares and about 3 thousand people from all over the world, making it difficult to determine its ethnic composition. The state of Nauru in Polynesia has territory of about $24 \mathrm{sq} . \mathrm{km}$ and a population of 10 thousand man.

Individuals and their societies are objective realities, acting more or less successful without recognition and support of anyone from the outside. Why the political institutions generated 
by these societies as their security services should be considered 'needing' such recognition? Usually any recognition is a formal act, so to speak, an expression of the existing states' consent to consider a new political entity as a member of the consisting of them international system and their readiness to cooperate with it. Will this happen or not depends on many factors: on relationship between the states, geopolitical considerations, etc. Therefore, readily acknowledging the potential new allies in competition on the world stage, some states deny this to the peoples close to their real or imagined opponents. In some cases, even lack of the recognized criteria of the statehood can be ignored. So, the state of Israel was recognized by many countries in 1948 without clearly defined boundaries and composition of its population. Objectively the main criteria the state's legitimacy are: 1) it is formed by a real society itself (an indigenous people or community of the peoples with areas of their historical habitation) as its institution for the protection of human rights and security; 2) it is recognized and supported by constitutional majority the society's members and 3) its readiness truly servicing to own society in compliance with generally accepted norms of the national and international law. These criteria (with possible concretization and development) should be considered as the criteria of international law as well.

Recognition does not create a state, just as no recognition doesn't make a really functioning state 'non-existing' and 'illegitimate'. It can only talk about the desirability and undesirability of the emergence of the new political entities for the existing states. Netherlands, proclaimed their independence in 1581 and had defend it in a bitter and protracted fight with the colonizers, were recognized by their former metropolis (Spain) only in 1648. The United States were recognized by the United Kingdom, only seven years after the adoption of the Declaration of independence. Many states did not recognize the Peoples Republic of China until 1970. Taiwan also is not considered a recognized state, although prior to recognition of the Peoples Republic of China, the government of this island represented China in the UN and its Security Council as a permanent member with veto power on the will of all the other member states of the world Organization. Taiwan as an actor of the multidimensional international relations remained actively functioning entity in international politics in the following decades as well. Although the Russian Federation does not recognize Taiwan's independence, de facto it is a quite successful market for goods produced in Taiwan, especially in the field of electronics. International law also considers with this reality. So, the article 13 the Organization of American States' Charter, proclaims that "The political existence of the State is independent of recognition by other States. Even before being recognized, the State has the right to defend its integrity and independence, to provide for its preservation and prosperity, and consequently to organize itself as it sees fit, to legislate concerning its interests, to administer its services, and to determine the jurisdiction and competence of its courts. The exercise of these rights is limited only by the exercise of the rights of other States in accordance with international law" [15].

Thus, the rule, according to which only the recognition of the will of the people by the majority of 'veteran states' makes the new entities legitimate, is arbitrary and lawless. Of course, the states, as well as the individuals, can treat each other differently - respectfully, indifferently, distrustfully, hostile or just not noticing each other at all; they try to divide and weaken some of them and reinforce the other. But peoples and their institutions do not stop being who or what they are. The United States refused to recognize the Soviet Union for fifteen years, and the People's Republic of China - almost thirty years. Yes, of course, it creates considerable difficulties to the young entities in their progress: they remained isolated from a large part of the external world, and therefore are limited in their opportunities for cooperation and collaboration, cannot use the advanced achievements of other peoples, to establish mutually 
beneficial trade and economic and other ties with them, and so on. It also slows progress of all humankind, giving rise to tensions in certain regions of its Habitat.

At the same time, the said in no case does mean condemnation of any sanctions against other countries. Probably, the problem is not so easy. Modern international law not without serious reason considers economic, cultural, diplomatic and other limitations, as well as limitation the states-transgressors' right to participate in international law-making processes more humane forms and ways to influence on countries flagrantly violating the law than the use of destructive military force. They were provided for in the Covenant of the League of Nations and the UN Charter, in statuses of all continental and regional organizations. But here is something to ponder over. Use of ill-considered restrictions often turns into an act aimed primarily against the peaceful people in the subjected to sanctions countries. The ruling circles whose behavior became the reason for imposition of the sanctions, almost do not feel their consequences of; they are well protected, not hungry, do not freeze, do not suffer from a lack of medicines and so forth. Only innocent people suffer and die from curable diseases. Truly democratic societies should not resort to anti-democratic measures; sanctions should be targeted to the perpetrators of violations of international law personally - to the first persons of the states concerned and their adepts. But somehow the states and international institutions are trying to avoid such measures. So, in September 11, 2017 the UN Security Council debated a draft resolution of the United States, which provided full and comprehensive limitation of economic, trade and other relations with the North Korea for its policy in the field of nuclear weapons. On the eve of the North Korea conducted a successful test of the thermonuclear weapon with capacity 20 times greater than the bomb the United States dropped on Hiroshima August 6, 1945. Half of the members of the Security Council themselves have such weapon and, essentially, under the slogan 'non-proliferation of nuclear weapons', try to protect their monopoly on it. The representative of the Russian Federation stated that Russia votes for the resolution 'because of the North Korean nuclear ambitions'. They believe that the right to such ambitions have only the 'great and powerful' states. The draft contained a paragraph about imposing sanctions on the North Korean leadership, but due to the insistence of the majority of the 'champions of equality and justice' it has been deleted from the document.

It is wrong to consider recognition of the state by the United Nations as a mandatory criterion of its legitimacy as well. The UN has no right to recognize or not recognize the states. According to its Charter, «Nothing contained in the present Charter shall authorize the United Nations to intervene in matters which are essentially within the domestic jurisdiction of any state or shall require the Members to submit such matters to settlement under the present Charter; but this principle shall not prejudice the application of enforcement measures under Chapter VII", considering the UN action with respect to threats to the peace, breaches of the peace, and acts of aggression [16Устав, 1945, Article 2, paragraph 7].

Any State can represent their country at the U.N. as a full member if it wants, when it establishes diplomatic relations with the majority of UN Member States, including members of the Security Council. When discussing the question of membership in the Organization at the UN General Assembly the states-members of the UN should be guided not by likes or dislikes, but by readiness of the new State to follow in its activities the principles of democracy and international law. In the meantime, some of them willingly recognizing and even encouraging to autonomy the peoples belonging to the 'hostile' nations-states, with a view to reducing their influence in the world, deny such right of the peoples with close to them states, calling them 'terrorists and separatists', although these processes occur about equally [18Мутагиров 2016]. 


\section{CONCLUSIONS}

There is some misunderstanding of the importance of the practical implementation of the right to self-determination by all peoples of the world, aspiring to independence. "If every ethnic, religious or linguistic group will claim its statehood, there will be no limit to fragmentation, and very difficult to achieve peace, security and economic well-being for all," declared in 1994 the then UN Secretary General Boutros-Ghali [19, p. 474]. Some researchers in the field of ethno-political studies agreed with Boutros-Ghali. Considering that there are about 15000 cultural groups in the world, A. Harrel wrote, it seems, the idea of statehood as a basic condition for the recognition of cultural equality is clearly incompatible with any stable international order» [20, p. p. $137-138]$.

Judgments of distinguished colleagues seem to us early ripening. Firstly, the right to selfdetermination up to their own states have only ethnic communities. Religious, cultural and linguistic groups are entitled only with the right to autonomy. Secondly, fears about 'difficulty to achieve peace, security and economic well-being for all' are devoid of any grounds. International Bill on human rights recognizes the autonomy and equality almost seven and a half billion people on the planet. But here we have some one thousand or more ethnic groups, potentially be able to organize own states. With regard to 'possible ethnic conflicts' [21, p. 95], much more of them occur at the individual and group levels, frequency of which depends on the degree of implementation of human rights and freedoms, democracy and the rule of law, than between the independent peoples. Freely evolving as self-governing ethnic groups, they would seek rapprochement with similar ethnicities, form the unions, federations and confederations of peoples according to new, more equitable and acceptable to all principles that will ultimately contribute to the best understanding of their common interests as detachments of the unique humankind.

At the beginning of the 20 th century there were 60 sovereign States in the world, by the middle of the twentieth century - 74 and after another half a century - 193, i.e. there was an increase of more than threefold. There are still fifty so-called 'unrecognized' states and self-governing territories. When there was more democracy, justice, the rule of law, and were considered with the human rights and freedoms in the world - in the beginning of the 20th or early 21st century? The increased number of the sovereign peoples was accompanied by elimination of some injustices, considerably diminished painful points in the world, many former zones of struggle and instability have become relatively calm. Therefore, FINAL ACT of the CONFERENCE ON SECURITY AND CO-OPERATION IN EUROPE once again proclamed: "The participating States will respect the equal rights of peoples and their right to selfdetermination, acting at all times in conformity with the purposes and principles of the Charter of the United Nations and with the relevant norms of international law, including those relating to territorial integrity of States. By virtue of the principle of equal rights and self-determination of peoples, all peoples always have the right, in full freedom, to determine, when and as they wish, their internal and external political status, without external interference, and to pursue as they wish their political, economic, social and cultural development. The participating States reaffirm the universal significance of respect for and effective exercise of equal rights and selfdetermination of peoples for the development of friendly relations among themselves as among all States; they also recall the importance of the elimination of any form of violation of this principle" [22, VIII].

Human history confirms, that social processes in the world occur by multiple 'negations of denial'. Thousands of relatively independent actors of these processes in early history gradually merged, either voluntarily or by force in a few hundred, and then dozens of the states. Colonial empires and 'federations' of unequal subjects had formed, after the collapse of 
which dozens of new political entities shaped, whose experience in case of their successfully development will encourage to independence all other peoples of the world, the descendants of which will form new unions, federations and confederations, but already absolutely voluntarily and exclusively on democratic basis [23Мутагиров, 2014].

\section{References:}

Carneiro R. (1970). A Theory of the Origin of the State. Science, № 169 (3947), pp. 733-738.

Cassel Allan. (2001) Ideology and international relations in the modern world. Taylor \& Francis, 2003.

The Declaration of Independence. The Want, Will, and Hopes of the People. URL:

http://www.ushistory.org/DECLARATION/document/

The so-called 1993 Constitution of the Russian Federation was not approved, by "more than half of the citizens, included in the electoral lists," as the law 'On referendum' (1990) required. In 13 of 21 Republic, 19 of 55 areas and two autonomous districts of the Russian Federation, most of the citizens had voted against the Constitution's draft, and in 86 subjects of the Federation it was approved by less the half citizens, but nevertheless it was declared entered into force. By whom and on what basis was done this? Definitely legal scholars, considering that "in Russia there is no legitimate political power, ... Constitutional rights remain insufficiently implemented in Russia today" are right? [Steven Holmes. To what Russia teaches us today? //Constitutional law: Eastern European review, 1997, no. 3-4 c. 195].

International Covenant on Civil and Political Rights Adopted and opened for signature, ratification and accession by General Assembly resolution 2200A (XXI) of 16 December 1966, entry into force 23 March 1976, in accordance with Article 49). URL: http://www.un.org/ru/documents/decl_conv/hr_bill.shtml.

International Covenant on Economic, Social and Cultural Rights. Adopted and opened for signature, ratification and accession by General Assembly resolution 2200A (XXI) of 16 December 1966 entry into force 3 January 1976, in accordance with article 27

Lewis, M. Paul, Gary F. Simons, and Charles D. Fennig (eds.). 2016. Ethnologue: Languages of the World, Nineteenth edition. Dallas, Texas: SIL International. Online version: http://www.ethnologue.com.

Hobbes T. The English Works, vol. III. (Leviathan) [1651]. Liberty Fund, Indianapolis, 2011. 378 p

Carl Schmitt, Der Leviathan in der Staatslehre des Thomas Hobbes: Sinn und Fehlschlag eines politischen Symbols (1938; Stuttgart: Klett-Cotta, 1995).

Kennan G. (1952) American Diplomacy (New York: New American Library). 120 p.

Schlesinger Arthur, Jr. The Necessary Amorality of Foreign Affairs. Harper's Magazine 243, no. 1,455 (August 1971), pp. $72-73$.

Spykman N. (1942). America's Strategy in World Politics, New York. Harcourt.

Mutagirov D. Z. law's aspects of ethno political crisis // Vestnik of Saint Petersburg University. 2015. Issue 6, no. 1. pp. 14 - 24).

Rights and Duties of States-Convention Signed at Montevideo, December 26, 1933. Source: U.S., Department of State, Publication 1983, Peace and War: United States Foreign Policy, 1931-1941(Washington, D.C.: U.S., Government Printing Office, 1943, pp. 198-203.10. The Convention on the rights and duties of States (city of Montevideo, December 26,1933). 11. Charter of the Organization of American States. URL:http://www.oas.org/juridico/english/charter.html. Access 11.09.2017.

CHARTER OF THE ORGANIZATION OF AMERICAN STATES (A-41). Signed in Bogotá in 1948 and amended by the Protocol of Buenos Aires in 1967, by the Protocol of Cartagena de Indias in 1985, by the Protocol of Washington in 1992, and by the Protocol of Managua in 1993.URL: http://www.oas.org/juridico/english/charter.html

Charter of the United Nations. 1945. URL: http://www.un.org/ru/charter-united-nations/index.html.

Mutagirov D. Z. Contemporary terrorism: Nature, causes and conditions for the eradication). Politbook, 2016, № 1, pp. $44-66$.

Morgenthau, H. J. (1948) Politics among Nations: The Struggle for Power and Peace, New York: Knopf. 1948. 688 p.

Agenda for Peace', 31 January 1992, reprinted in Adam Roberts and Benedict Kingsbury (eds.), United Nations, Divided World: The UN's Roles in International Relations, 2nd edn. (Oxford: Oxford University Press, 1993), 
Hurrel A. On Global Order. Routlage, 2005, p. 137 - 138.

Harold L Horowitz. Ethnic Groups in Conflict, 1989.

CONFERENCE ON SECURITY AND CO-OPERATION IN EUROPE. FINAL ACT. HELSINKI 1975. URL:

https://www.osce.org/helsinki-final-act

Mutagirov D. Z. Democracy as a universal value. Moscow, Logos, 2014. 